\title{
Migration Letters
}

March 2021

Volume: 18 , No: 2, pp. $121-133$

ISSN: 1741-8984 (Print) ISSN: 1741-8992 (Online) journals.tplondon.com $/ \mathrm{ml}$

Received: 13 October 2020 Accepted: 31 October 2020

DOI: https://doi.org/10.33182/ml.v18i2.1174

\section{Transnational (Im)mobilities and Informality in Europe}

\author{
Ignacio Fradejas-García ${ }^{1}$, Abel Polese ${ }^{2}$, and Fazila Bhimji ${ }^{3}$
}

\begin{abstract}
People around the globe rely on informal practices to resist, survive, care and relate to each other beyond the control and coercive presence of institutions and states. In the EU, regimes of mobility at multiple scales affect various people on the move who are pushed into informality in order to acquire social mobility while having to combat border regimes, racialisation, inequalities, and state bureaucracies. This text explores how mobilities and informality are entangled with one another when it comes to responding to the social, political, and economic inequalities that are produced by border and mobility regimes. Within this frame, the ethnographic articles in this special issue go beyond national borders to connect the production of mobility and informality at multiple interconnected scales, from refugees adapting to settlement bureaucracies locally to transit migrants coping with the selective external borders of the EU, or from transnational entrepreneurs' ability to move between formal and informal norms to the multiple ways in which transnational mobility informally confronts economic, social and political constraints. In sum, this volume brings together articles on informality and mobility that take account of the elusive practices that deal with the inequalities of mobility and immobility.
\end{abstract}

Keywords: informality; (im)mobility; transnationalism; Europe; mobility regimes; informal practices

\section{Introduction}

Humanity's ever-increasing mobilities around the globe are commonly dichotomised between the mobilities of the undeserved and the deserving on the move. While violent conflicts, natural disasters, poverty and political repression are causing the involuntary mobility and immobility of millions, tourists, businesspeople and other cosmopolitans have access to a wider degree of mobility. The dichotomy between privileged global citizens and unwanted, stigmatised migrants, undocumented or not, excludes those who are betwixt and between. By bringing together wanted and unwanted human mobilities in Europe (Loftsdóttir, 2018), we look at the unequal relations and structures of power that limit or facilitate mobility and immobility - hereafter (im)mobilities - within transnational social fields (Glick Schiller \& Salazar, 2013), as well as enquire into the daily informal activities that respond to the unequal distribution of motility, that is, the potential to be mobile (Kaufmann, Bergman, \& Joye, 2004).

As a starting point, mobility generates social and cultural change at various scales (King \& Skeldon, 2010) and boosts transnational activities, connections, linkages, positions, and belongings across national borders (Dahinden, 2017). Globally, the climate, urban, and

\footnotetext{
${ }^{1}$ Ignacio Fradejas-García, Universitat Autònoma de Barcelona, Spain. E-mail: Ignacio.Fradejas@uab.cat.

2 Abel Polese, Dublin City University Dublin, Ireland. E-mail: abel.polese@dcu.ie.
}

Acknowledgement: Part of this research was supported by a Marie Curie Research and Innovation Staff Exchange scheme within the H2020 Programme (grant acronym: New Markets, no: 824027).

${ }^{3}$ Fazila Bhimji, University of Central Lancashire, Preston, United Kingdom. E-mail: FBhimji@uclan.ac.uk. 
migration crises have created new challenges for how power and inequality inform the governance and control of mobilities (Sheller, 2018). The climate crisis is affecting the urge for greener mobilities and decarbonised transportation, while with more than half of the global population living in cities, urban mobilities are impacted by excluding some populations from public spaces and privileging others. Moreover, racism and xenophobia directed against migrants and other people on the move is on the rise, nurtured by extreme right-wing parties (Rossell Hayes \& Dudek, 2019) and making some categories of people on the move more vulnerable. The same can be said for the current COV19 lockdown. It has been estimated that worldwide 1.6 billion informal workers face the dilemma of risking contagion by working outside their homes or remaining immobile at home and dying of starvation (ILO, 2020).

In some cases, formal structures can help people cope with the new demands arising from mobilities. The process of European integration has strongly fostered work- or family-related mobilities: according to Eurostat (2018), 19.3 million European Union (EU) citizens are residing in a country different from the one they were born in. Within this context of the increasing internal mobility of people, things, ideas and services, even a fairly well-regulated framework like the EU is likely to reveal inequality, or at least a lack of social or economic evenness. However, in certain other cases, current structures, formulas and institutions are shutting their doors and placing hurdles in the way of certain mobilities with mobility regimes at different levels (Glick Schiller \& Salazar, 2013): "even those who have obtained citizenship are increasingly at risk for surveillance, harassment and even deportation" (Glick Schiller, 2018: 206). As a result, a heterogeneous group of people on the move is being disregarded, resulting in their being increasingly pushed into informal practices and informality in order to cope with the fetters of control and the securitisation of undeserved mobilities.

Much has been written about informality since the seminal work of Keith Hart (1973). Initially the word was used to refer to economic phenomena, but further consideration expanded the scope of research on informality to include any activities that are deliberately concealed from the state. Informal practices, defined as activities that happen outside the controlling or coercing presence of one or more states or their institutions (Routh, 2011) may be regarded as a mechanism limiting or reversing the unequal situations experienced by those who are formally excluded for a variety of reasons in respect of access to services, capital, and opportunities. This introduction argues that geographical mobilities and informality are entangled with one another when it comes to responding to the social, political, and economic inequalities that are produced by border and mobility regimes.

In what follows, this introduction unpacks and connects the literature on transnational (im)mobilities and informality and sets the scene for the collection of articles presented in this special issue. ${ }^{4}$ This collection brings together contributions that provide further empirical evidence of the existence, performance, and persistence of informal practices, and/or explore the relationships between transnationalism, (im)mobility, and informal practices in western Europe. To this end, our aim is to fill a gap in studies combining mobilities and informality, contribute to the still incipient post-structuralist research into informal practices in west

\footnotetext{
${ }^{4}$ This special issue has its roots in a panel convened by Ignacio Fradejas-García and Abel Polese at the SIEF conference in Santiago de Compostela (Spain) in April 2019 entitled "Transnationalism, (im)mobilities and informal practices in Europe, and beyond". Selected papers were discussed in a similarly named workshop at the MIDEX Center at the University of Central Lancashire on $7^{\text {th }}$ February 2020.
} 
Europe, and provide a nuanced understanding of the production of informality by geographical and social (im)mobilities.

\section{Transnational (im)mobilities and informality}

The transnational paradigm highlights the importance of the social, political, and cultural practices that link places of origin and settlement (Basch, Glick Schiller, \& Szanton Blanc, 1994; Glick Schiller, Basch, \& Blanc-Szanton, 1992). Approximately one third of migrants relationships are transnational (Lubbers, Verdery, \& Molina, 2018) and some critics argue that not all migrants participate regularly in transnational activities (Portes, Guarnizo, \& Landolt, 1999), overlooking the fact that this is a matter of the degree of involvement in transnational practices, as studies of informal social support have shown (Bilecen \& Sienkiewicz, 2015). Other critics have identified a social convergence between the societies of origin and destination (Waldinger, 2015), a view that reinforces the notion of methodological nationalism (Wimmer \& Glick Schiller, 2002), which assumes the existence of "social and cultural homogeneity within the unit of the nation state as well as within the migrant population" (Glick Schiller and Salazar, 2013: 3). In order to avoid these limitations here, we adopt a multiscalar analysis "where local, regional, national, pan-regional and global are not separate levels of analysis, but rather are part of mutually constituting institutional and personal networks of unequal power within which people, both with and without migrant histories live their lives" (Glick Schiller, 2015: 277).

The mobilities turn has placed the movement of people, things and knowledge at the centre of social analysis and claims that theories of migration and transnationalism are valuable but limited when it comes to researching the importance of opportunities and constraints on mobility and immobility for day-to-day lives (Cresswell, 2006; Hannam, Sheller, \& Urry, 2006). Within this paradigm all forms of mobility might be addressed, thus questioning the objects of social enquiry and developing new methodologies (Sheller \& Urry, 2006). Observing a basic signifier of mobility that is moving from point $A$ to point $B$, migration and push-pull theories fail to explore the intermediate line connecting these two points (Cresswell, 2006). As only the beginning and end of the process are visible, there is a persistent tendency to ignore what is happening in between those two points. This is not just a physical or geographical concern: by defining informality as the "space between two formal rules" (Polese, 2016: 26), it has become clear that processes of getting to a destination are as important as the outcome, the fact that you got there, or did not. It is thus by understanding international migration as one type of mobility among others that we can shed light on transnationalism as a paradigm that connects migration with mobilities, thus allowing vertical and horizontal analyses at various scales.

Within this framework, we contend that even migrants with illegal status and therefore limited geographical mobility depend on informal transnational networks for social support and are connected through social and economic remittances with their countries of origin (e.g. Mazzucato, 2011). Indeed, knowledge and things are an important part of the transnational flexibility of maintaining personal networks. Accordingly, rather than perceiving migration, mobilities, and transnationalism as incompatible, we merge these concepts in order to acquire a more nuanced understanding of current systems and regimes of mobility.

The regimes of mobility dealt with here are approached from both functionalist and discursive perspectives (Baker, 2016). On the one hand, the functionalist approach looks at the norms, 
policies, regulations, and infrastructure that govern movement and mobile subjects (Jensen, 2013; Kesselring, 2014; Koslowski, 2011). On the other hand, the discursive approach seeks to understand how power structures shape the mobility and stasis of individuals through categories such as race or class (Glick Schiller, 2018; Glick Schiller \& Salazar, 2013). Consequently, the question here shifts from the amount and duration of mobilities to "how the formation, regulation, and distribution of these mobilities are shaped and patterned by existing social, political, and economic structures" (Salazar, 2014: 60). By way of example, transnational mobilities are also shaped by ethnic enclaves (Molina, Valenzuela-García, Lubbers, García-Macías, \& Pampalona, 2015), supranational organizations (Fradejas-García \& Mülli, 2019) or gendered transnational connections (Zani, 2019).

Since being coined, the word "informality" has been used to refer to several different, although related, phenomena. As already noted, Keith Hart was probably the first scholar to identify, and study, a number of informal economic practices (1973). However, the International Labor Organization's interest in informal labor from 1972 opened the debate to various disciplines and approaches. The work of Scott on moral economies (1976) and the power relationships between peasants and their landowners (1985) have been followed by economic anthropologists (Hann \& Hart, 2011). Policy-makers and political scientists unlocked debates on the effective governance of post-colonial states (Leff, 1964; Palmier, 1983). Critical post-socialist studies found inspiration in informality as a way of opening up the discussion on development, governance, and corruption, as well as questioning the mainstreaming of imported practices, mechanisms, and institutions from the West (Humphrey, 2002; Jancsics, 2013; Millington, Eberhardt, \& Wilkinson, 2005; Polese, Morris, Kovács, \& Harboe, 2014). Informality is now seen as a socially embedded phenomenon (Granovetter, 1983) found in all segments of societies worldwide (Morris \& Polese, 2014) that is not limited to the economic sphere, but is integrated into society and state governance (Polese, Williams, Horodnic, \& Bejakovic, 2017).

The question here concerns the subjective boundaries and legal differences between informal and criminal activities. The matrix below (see Table 1), taken from Van Schendel and Abrahams (Schendel \& Abraham, 2005), separates legal/illegal and licit/illicit, where the licit might be illegal but nonetheless socially acceptable to all or some segments of a population. There is a second notion based on direct and indirect harm (Polese, 2015). Murder harms a society since it deprives it of its labor force, but it also directly harms a fellow human being. Trafficking, kidnapping, and theft follow the same logic. However, fiscal noncompliance mainly harms the state and only then, and only indirectly, fellow citizens. A lower fiscal income either puts more pressure on honest taxpayers or reduces the amount available for the state's population. Nontransparent hiring practices rarely harm a single person directly (unless that person is given a job and then deprived of it in a last-minute change), but it can indirectly harm society by placing incompetent individuals in key positions. For example, informal enterprises and hiring practices may break official rules, dispense with permits, and avoid taxes, but they are not obviously criminal because they provide income-earning opportunities and goods and services that are necessary and/or desired by the public (Bromley \& Wilson, 2018). 
Table 1. The relationship between legality and licitness adapted from (Schendel \& Abraham, 2005), and direct (affecting fellow citizens), indirect (affecting a society) harm and legality.

\begin{tabular}{|c|c|c|c|c|}
\hline & \multicolumn{2}{|c|}{ Legal } & \multicolumn{2}{|c|}{ Illegal } \\
\hline \multirow[t]{2}{*}{ Licit } & \multirow[t]{2}{*}{$\begin{array}{l}\text { State and social norms } \\
\text { overlap }\end{array}$} & \multicolumn{2}{|c|}{ Indirect harm (might be licit) } & $\begin{array}{l}\text { Society allows } \\
\text { something that is } \\
\text { forbidden by state } \\
\text { institutions or codes }\end{array}$ \\
\hline & & $\begin{array}{l}\text { Laws that favor one } \\
\text { (ethnic, religious) group } \\
\text { over others (are licit for } \\
\text { the favored ones) }\end{array}$ & $\begin{array}{l}\text { Fiscal fraud, } \\
\text { nepotism, ethnic or } \\
\text { religious } \\
\text { discrimination }\end{array}$ & \\
\hline \multirow[t]{2}{*}{ Illicit } & \multirow{2}{*}{$\begin{array}{l}\text { The state does not } \\
\text { punish actions that are } \\
\text { stigmatised socially (by } \\
\text { one or more } \\
\text { communities) }\end{array}$} & \multicolumn{2}{|c|}{ Direct harm (mostly illicit) } & $\begin{array}{l}\text { State and social } \\
\text { norms overlap }\end{array}$ \\
\hline & & $\begin{array}{l}\text { Use legal action against } \\
\text { the unaware to extort } \\
\text { money or property; } \\
\text { clauses written in a } \\
\text { smaller font at the end } \\
\text { of a contract }\end{array}$ & $\begin{array}{l}\text { Murder, trafficking, } \\
\text { heavy drug dealing, } \\
\text { ethnic violence } \\
\text { (might be licit in } \\
\text { some cases) }\end{array}$ & \\
\hline
\end{tabular}

The above matrix acts to circumscribe the scope of this special issue and to suggest the range of activities that are not regulated by the state (Routh, 2011) but are either socially acceptable or do not harm fellow human beings directly. Although many operating in the informal sector might suggest that "a little bit of informality" will not harm someone "too much," there is no evidence for this. A single failure to comply with tax obligations will not harm the state's capacity per se, but when this happens a million times, what Scott (2012) calls "infrapolitics," the aggregate affect may be to reduce the budget allocated to healthcare and consequently the capacity of public hospitals to treat patients. This may result in higher mortality rates and a larger number of individuals going to private hospitals. This is also why informality then happens "in spite" of the state, through parallel mechanisms that replace state structures or stretch "beyond the state" to reach spheres of governance that the state is unwilling or unable to deal with (Davis \& Polese, 2015; Polese, Kovács, \& Jancsics, 2018). Inasmuch as direct and indirect harm cannot be understood in absolute terms, they nonetheless provide an initial interpretative framework that allows informality to be seen not as intrinsically negative and obnoxious, but as a component of state governance. 


\section{Looking for new recipes: informal practices along European (im)mobilities}

Of course, we need to weigh up the pros and cons of mobilities and informality as overarching concepts. Both permit interdisciplinary dialogue, bring together social processes that are apparently disconnected, and relate basic research to policy-making. However, the problem is lazy and/or ad-hoc definitions that make these conceptualisations useless. Peter Adey's article "If Mobility is Everything Then it is Nothing: Towards a Relational Politics of (Im)mobilities" (Adey, 2006) argues that, while everything may be on the move, it can all appear fixed and stable because there are different types of mobility, requiring a "relational politics of (im)mobilities that takes into account not only the differences between movement, but their contingent relatedness" (Adey, 2006: 90). However, the dialectical understanding of dichotomies such as that between mobility and immobility needs to go beyond the asymmetrical tautology that axiomatically takes as passive one of the poles: that is, mobile cosmopolitans versus immobile locals (Franquesa 2011). Similarly, informality and formality need each other to operate, it being desirable to go beyond the asymmetrical view that takes informality to be the result of formal constraints. The present focus on the formal-informal continuum (Morris \& Polese, 2014) is the best strategy for avoiding the "hierarchical binary mode of thought" (Derrida cited in Williams and Onoshenko 2014: 22). Indeed, looking at how these concepts intersect in social practices, we can play with words in order to tie the ends together and talk about (im)mobilities and (in)formalities.

The Global Encyclopaedia of Informality (Ledeneva, 2018) and countless books and articles from various disciplines may leave the impression that everything to do with informality has already been said and done. Undoubtedly, informality research is no longer radical. However, we argue that by changing our spectacles and working in parallel with other paradigms, there is still room to develop social theory further and to increase our understanding of complex systems. Thus, while there is a good body of literature on migration-related issues and informality in Europe (e.g. Baldwin-Edwards and Arango 1999), as well as some studies about 'transnational informality' in post-socialist spaces (e.g. Cieslewska 2014; Yalcin-Heckmann 2014; Turaeva 2014; Urinboyev and Polese 2016), mobilities - broadly conceived - have remained relatively understudied in connection with informality. Thus, taken as a whole, this special issue makes three contributions to the current debate on informality and mobility.

First, it provides empirical evidence about informality in west European countries and moves beyond post-socialist countries, the Global South and the development settings in which informality research has been mostly grounded. Nowadays, the vast literature on informality acknowledges its ubiquity but is mostly based on evidence from non-western contexts. For example, in the Global Informality Project there are 57 entries for the EU out of the total of 250 , only $29^{5}$ of which are in non-post-socialist EU countries. Similarly, we see the same phenomenon in some compilations on global informality with contributions from all around the world (Polese, Russo, \& Strazzari, 2019; Polese et al., 2017), but there is less scholarship specifically examining European contexts.

It might be argued that there are fewer studies focusing on continents such as South America or Africa, but here the number of researchers and the availability of funding are not

\footnotetext{
${ }^{5}$ https://www.in-formality.com/wiki/index.php?title=Global_Informality_Project Practices in the EU: Italy (7), UK (7), Germany (6), France (2), Greece (2), Finland (2), Denmark, Norway and Sweden, Austria, Netherlands and Spain. For some countries, such as Belgium, Portugal and Cyprus, there are as yet no entries. [last accessed 1.03.2020]
} 
comparable. The reasons are varied, but the fact that informality is intertwined and embedded in formality in more complex ways in western contexts (Morris \& Polese, 2014) makes it more difficult to research. Finally, focusing on western informality takes us beyond the transitory and transitology aspects of the informal theories and governance systems that have been exported from western institutions and promoted in post-socialist and development contexts. Thus, this special issue aims to fill some of these gaps through a focus on researching informality in the EU and in western countries generally.

Second, using this framework we can sit at the same table with undeserved and deserving people on the move. The EU's unequal regime of mobility privileges the arrival of skilled immigrants through official migration channels (Sandoz, 2020) and/or promotes temporal or seasonal mobility programs of cheap labor from both among its own citizens (Caro, Berntsen, Lillie, \& Wagner, 2015) and outside the EU (Molinero Gerbeau et al., 2016), while coercing the other mobilities of unwanted and racialised populations. In the last three decades, the growing and expanding borders of the EU have refashioned the business of illegality (Andersson, 2014), forcing migrants to risk their lives to cross borders or to live in fear within the EU because of their deportability (De Genova, 2002). The so-called "refugee crisis" of 2015 made visible a regime of deservingness, opposing vulnerable refugees to opportunistic and unworthy (im)migrants who had voluntarily and freely made the choice to cross borders to seek a better life (Holmes \& Castañeda, 2016). The deterioration of living conditions after the long financial crisis and the related rise in populism, nationalism, and racism in Europe made people on the move the target and subjected them to being controlled by an increasing body of rules (Likic-Brboric, Slavnic, \& Woolfson, 2013). The "deservingness" regime has expanded to most national aliens. Thus, the border plays the double role of contention externally and of the threat of deportability internally. The European border regime (Hess \& Kasparek, 2017) is thus a double-edged sword of Damocles for non-EU citizens who have not had the full privilege of moving freely within the EU, thus forcing people to live in the grey areas where informality reigns.

Moreover, the celebrated "freedom of mobility" within the EU has several implications for how mobility shapes informality. Mobility control is exercised at other scales, such as emplacement in cities, labor rights, access to documents or daily racialisation in being policed. Thus, although informality might be produced by mobility itself, mobility never occurs devoid of regulation. Regimes of mobility at various scales (Glick Schiller \& Salazar, 2013) are the key to understanding how different people on the move rely on informal practices. Thus, this special issue contributes to shedding light on how the EU and national regimes of mobility generate illegal apparatuses governing both the internal and external mobilities that forces people to rely on informal practices. The question here is, do the mobilities of internal EU immigrants and international (undocumented) immigrants produce different informal practices?

Third, we are not only looking at geographical movement but also at social mobility, especially upward mobility. Physical and socio-economic mobilities are entangled in migration and transnational mobilities in many ways. Indeed, in many cases transnational mobilities are fostered not by ideology but for work chains promoted by global capitalism (Portes, 2001). In this complex understanding of mobilities, we need to address the relationship between mobility and immobility, which has not so far been a focus of attention within migration studies. Accordingly, informal practices might be regarded as ways of improving the socio- 
economic situations of individuals or groups, not limited to survival strategies but to opening up a space for informal practices among elites and those who are accommodated.

\section{Ethnographies of informality and (im)mobility in this volume}

The informal practices and transnational (im)mobilities of people, ideas, and objects are pervasive and intrinsically elusive. The former operate in grey areas of daily life: "they are often invisible, resist articulation and measurement, and hide behind paradoxes, unwritten rules and open secrets" (Ledeneva 2018: 7). The later are socially embedded, the social structures that permit activity being inherently difficult to analyse and measure as a whole because they work simultaneously at various scales and places (Lubbers et al., 2018). Given this complex research environment, the ethnographic studies presented in this volume are based in a "long-term and open-ended commitment, generous attentiveness, relational depth, and sensitivity to context" (Ingold, 2014: 384) that allows the authors to offer a deep understanding of specific social practices.

As the above discussion has demonstrated, the idea of informal practices has been extensively discussed in different contexts, but there has been relatively less analysis of the way we come to understand informal endeavours when people on the move are pushed into informality in order to acquire social mobility while having to combat border regimes, racialisation, inequalities, and state bureaucracies. Linking mobility and informality gives this special issue a coherence in that it advances existing knowledge on informality in western Europe and goes beyond previous accounts of informality and migration. Based on evidence from non-postsocialist and non-Global South contexts, such as Spain, Germany, the UK, and Greece, and two mobility corridors between post-socialist and western contexts, namely Finland-Estonia and Romania-Spain, the articles in this collection provide ethnographic analyses of the rich connections between transnationalism, mobilities, border regimes, and informal practices.

Three of the articles in this issue demonstrate the connections between the inequalities of transnational mobilities and the informal practices that people carry out in making a living. Thus, Laure Sandoz critically explores the concepts of informality and entrepreneurship in a situation of unequal access to formal resources. Grounded in the example of transnational entrepreneurs in Barcelona, she argues that an entrepreneurial ability to mobilise economic, cultural, social, and moral resources is key to managing formal or informal norms in a given context. Ignacio Fradejas-García interrogates the role of the automobile system and of informal practices in migrants' daily work and life mobilities. Based on multi-sited ethnographic fieldwork among low-wage transnational Romanian immigrants in Spain, Fradejas-García defines informal automobilities as a set of livelihood strategies and infrapolitical activities that use cars to confront the constraints of geographical and social mobility regimes in order to make a living. His findings are also relevant to thinking about the impact a carless or post-car world would have on populations that rely on the current automobility system to survive or oppose unequal regimes of mobility. Also drawing on transnational and translocal strategies, Pihla Maria Siim examines the persistent inequalities of mobilities and informal practices as she explains the ways in which informal, gendered, translocal care affects the everyday lives of Estonian family members in different ways when they migrate to Finland. In her study, she demonstrates how "skilled" and "professional" migrants enjoy the privilege of providing transnational care with relative ease as they move back and forth between Finland 
and Estonia in more flexible ways, in comparison to working-class migrants who are forced to find care through their networks and extended family members in Finland and Estonia.

This special issue includes a second set of four articles that analyse the links between border regimes, bureaucracies, and informal practices, as well as moral evaluations of these practices. Romm Lewkowicz's study demonstrates how 'unauthorised' migrants on the move evaluate passports and legal papers in terms of their efficacy to cross borders rather than legality or formality. Lewkowicz shows how the EU border regimes obscure how illegality is embedded in the legal/illegal distinction that criminalises asylum-seeking and depict migrants as agents or victims of illegality. Fazila Bhimji and Nelly Wernet show how refugees in Germany go "beyond the state" to defy rules and regulations related to movement within Germany and find ways to reside in Berlin, where they strive for social mobility by networking with informal associations that assist them with housing. In doing so, the refugees understand that their staying in Berlin is against the law, but they consider their decisions and actions necessary for their economic and social well-being.

Hilal Alkan analyses how refugees traverse border regimes with the help of human smugglers whom they refer to as simsars, especially when encountering housing and employment bureaucracies in Berlin and Leipzig. Alkan discusses the emic understandings and moral evaluations of her interlocutors in relation to the state's assessments: refugees denigrate the services of the simsars when they provide 'illegal' support with housing, but normalise the service of human smugglers. These views contradict the state's perceptions. Finally, Caroline Blunt shows the importance of informalities for refugees in a resettlement program in the UK. The lack of informal social infrastructure in the location of resettlement raises intriguing questions about how formal procedures can promote informality. Blunt asserts that, where an informal social infrastructure was available, refugees in these localities conveyed an experience of positive processes of life, resonating with Hage's (Hage, 2005) discussion of existential movement, and showing that, where this infrastructure was unavailable, refugees conveyed the experience of a persistent or even worsening sense of biographical interruption than that to which forced migration has generally been compared.

The contribution of the articles presented in this volume show how informality can be used to complement the state (or states), find solutions to novel problems arising from (im)mobilities, and enable access to services, capital, and opportunities for those who are formally excluded or constrained by EU mobility regimes. Mobility generates changes and challenges that are addressed in different ways. In the current overheated world (Eriksen, 2016), the human population is being stressed by simultaneous systemic and overlapped crises - climate, urban, migration, economic, identity, and now the COVID19 pandemic. Formal structures can help cope with the new demands rising from mobilities, but in certain other cases current structures, formulas and institutions are not able to respond. Future research on the links between (in)formalities and (im)mobilities could help us understand how to deal with the impact of the inequalities that are being generated by multiple global crises.

\section{Acknowledgments}

Ignacio Fradejas-García was supported by an FPI grant (BES-2016-076859), which is cofunded by the European Social Fund and the Ministry of Economy and Competitiveness of Spain, and by the ORBITS project, funded by the Ministry of Economy and Competitiveness of Spain (MINECO-FEDER: CSO2015-68687-P, 2016-2020). Abel Polese was supported by 
a Marie Curie Research and Innovation Staff Exchange scheme within the H2020 Programme (grant acronym: New Markets, no. 824027).

\section{References}

Adey, P. (2006). If Mobility is Everything Then it is Nothing: Towards a Relational Politics of (Im)mobilities. Mobilities, 1(1), 75-94. https://doi.org/10.1080/17450100500489080

Andersson, R. (2014). Illegality, Inc. Berkeley: University of California Press.

Baker, B. (2016). Regime. In N. B. Salazar \& K. Jayaram (Eds.), Keywords of Mobility. Critical Engagements. New York: Berghahn Books.

Baldwin-Edwards, M., \& Arango, J. (1999). Immigrants and the Informal Economy in Southern Europe. London: Frank Cass.

Basch, L., Glick Schiller, N., \& Szanton Blanc, C. (1994). Nations Unbound: Transnational Projects, Postcolonial Predicaments, and Deterritorialized Nation-States. Langhorne, PA: Gordon and Breach Science Publishers.

Bilecen, B., \& Sienkiewicz, J. J. (2015). Informal Social Protection Networks of Migrants: Typical Patterns in Different Transnational Social Spaces. Population, Space and Place, 21(3), 227-243. https://doi.org/10.1002/psp.1906

Bromley, R., \& Wilson, T. D. (2018). Introduction: The Urban Informal Economy Revisited. Latin American Perspectives, 45(1), 4-23. https://doi.org/10.1177/0094582X17736043

Caro, E., Berntsen, L., Lillie, N., \& Wagner, I. (2015). Posted Migration and Segregation in the European Construction Sector. Journal of Ethnic and Migration Studies, 41(10), 1600-1620. https://doi.org/10.1080/1369183X.2015.1015406

Cieslewska, A. (2014). From Shuttle Trader to Businesswomen: The Informal Bazaar Economy in Kyrgyzstan. In J. Morris \& A. Polese (Eds.), The Informal Post- Socialist Economy: Embedded Practices and Livelihoods (pp. 121-134). London and New York: Routledge.

Cresswell, T. (2006). On the Move: Mobility in the Modern Western World. New York \& London: Routledge.

Dahinden, J. (2017). Transnationalism Reloaded: The Historical Trajectory of a Concept. Ethnic and Racial Studies, 40(9), 1474-1485. https://doi.org/10.1080/01419870.2017.1300298

Davis, T., \& Polese, A. (2015). Informalidad y supervivencia en Chernobyl: etnografía de un espacio nuclear. Methaodos. Revista de Ciencias Sociales, 3(2), 221-238.

De Genova, N. P. (2002). Migrant "Illegality" and Deportability in Everyday Life. Annual Review of Anthropology, 31(1), 419-447. https://doi.org/10.1146/annurev.anthro.31.040402.085432

Eriksen, T. H. (2016). Overheating: The World Since 1991. History and Anthropology, 27(5), 469-487. https://doi.org/10.1080/02757206.2016.1218865

Eurostat. (2018). Migration and Migrant Population Statistics. Eurostat. Retrieved from http://epp.eurostat.ec.europa.eu/statistics_explained/index.php/Migration_and_migrant_population_ statistics\#Foreign_and_foreign-born_population

Fradejas-García, I., \& Mülli, L. M. (2019). (Im)mobile Workers: Entangled Regimes of (Im)mobility Within the United Nations System. Mobilities, 14(6), 906-922. https://doi.org/10.1080/17450101.2019.1669914

Franquesa, J. (2011). "We've Lost Our Bearings": Place, Tourism, and the Limits of the "Mobility Turn." Antipode, 43(4), 1012-1033. https://doi.org/10.1111/j.1467-8330.2010.00789.x

Glick Schiller, N. (2015). Explanatory Frameworks in Transnational Migration Studies: the Missing Multiscalar Global Perspective. Ethnic and Racial Studies, 38(13), 2275-2282. https://doi.org/10.1080/01419870.2015.1058503

Glick Schiller, N. (2018). Theorising Transnational Migration in Our Times: Nordic Journal of Migration Research, 8(4), 201-212. https://doi.org/10.2478/njmr-2018-0032

Glick Schiller, N., Basch, L., \& Blanc-Szanton, C. (1992). Transnationalism: A New Analytic Framework for Understanding Migration. Annals of the New York Academy of Sciences, 645(1 Towards a Tra), 1-24. https://doi.org/10.1111/j.1749-6632.1992.tb33484.x

Glick Schiller, N., \& Salazar, N. B. (2013). Regimes of Mobility Across the Globe. Journal of Ethnic and Migration Studies, 39(2), 183-200. https://doi.org/10.1080/1369183X.2013.723253

Granovetter, M. (1983). The Strength of Weak Ties: A Network Theory Revisited. Sociological Theory, 1, 201233. https://doi.org/10.2307/202051 
Hage, G. (2005). A not so Multi-sited Ethnography of a not so Imagined Community. Anthropological Theory, 5(4), 463-475. https://doi.org/10.1177/1463499605059232

Hann, C., \& Hart, K. (2011). Market and Society: The Great Transformation Today. Cambridge: Cambridge University Press.

Hannam, K., Sheller, M., \& Urry, J. (2006). Editorial: Mobilities, Immobilities and Moorings. Mobilities, 1(1), 1-22. https://doi.org/10.1080/17450100500489189

Hart, K. (1973). Informal Income Opportunities and Urban Employment in Ghana. The Journal of Modern African Studies, 11(1), 61-89.

Hess, S., \& Kasparek, B. (2017). De- and Restabilising Schengen. The European Border Regime After the Summer of Migration. Cuadernos Europeos de Deusto, (56), 47-77. https://doi.org/10.18543/ced-562017pp47-77

Holmes, S. M., \& Castañeda, H. (2016). Representing the "European Refugee Crisis" in Germany and Beyond: Deservingness and Difference, Life and Death. American Ethnologist, 43(1), 12-24. https://doi.org/10.1111/amet.12259

Humphrey, C. (2002). The Unmaking of Soviet Life: Everyday Economies after Socialism. Retrieved from https://doi.org/10.7591/9781501725722

ILO. (2020). COVID-19 Crisis and the Informal Economy Immediate Responses and Policy Challenges. Retrieved from https://www.ilo.org/wcmsp5/groups/public/---ed_protect/---protrav/--travail/documents/briefingnote/wcms_743623.pdf

Ingold, T. (2014). That's Enough About Ethnography! HAU: Journal of Ethnographic Theory, 4(1), 383-395. https://doi.org/10.14318/hau4.1.021

Jancsics, D. (2013). Petty Corruption in Central and Eastern Europe: The Client's Perspective. Crime, Law and Social Change, 60(3), 319-341. https://doi.org/10.1007/s10611-013-9451-0

Jensen, A. (2013). Mobility Regimes and Borderwork in the European Community. Mobilities, 8(1), 35-51. https://doi.org/10.1080/17450101.2012.747780

Kaufmann, V., Bergman, M. M., \& Joye, D. (2004). Motility: Mobility as Capital. International Journal of Urban and Regional Research, 28(4), 745-756. https://doi.org/10.1111/j.0309-1317.2004.00549.x

Kesselring, S. (2014). Mobility, Power and the Emerging New Mobilities Regimes. Sociologica, 1, 1-30. https://doi.org/10.2383/77047

King, R., \& Skeldon, R. (2010). “Mind the Gap!” Integrating Approaches to Internal and International Migration. Journal of Ethnic and Migration Studies, 36(10), 1619-1646. https://doi.org/10.1080/1369183X.2010.489380

Koslowski, R. (2011). Global Mobility Regimes: A Conceptual Framework. In R. Koslowski (Ed.), Global Mobility Regimes (pp. 1-25). New York: Palgrave Macmillan.

Ledeneva, A. (2018). The Global Encyclopaedia of Informality: Understanding Social and Cultural Complexity. Volume 1 \& 2. https://doi.org/10.14324/111.9781911307907

Leff, N. H. (1964). Economic Development Through Bureaucratic Corruption. American Behavioral Scientist, 8(3), 8-14. https://doi.org/10.1177/000276426400800303

Likic-Brboric, B., Slavnic, Z., \& Woolfson, C. (2013). Labour Migration and Informalisation: East Meets West. International Journal of Sociology and Social Policy, 33(11/12), 677-692. https://doi.org/10.1108/IJSSP10-2012-0087

Loftsdóttir, K. (2018). Global Citizens, Exotic others, and Unwanted migrants: Mobilities in and of Europe. Identities, 25(3), 302-319. https://doi.org/10.1080/1070289X.2016.1233879

Lubbers, M. J., Verdery, A. M., \& Molina, J. L. (2018). Social Networks and Transnational Social Fields: A Review of Quantitative and Mixed-Methods Approaches. International Migration Review, 019791831881234. https://doi.org/10.1177/0197918318812343

Mazzucato, V. (2011). Reverse Remittances in the Migration-development Nexus: Two-way Flows Between Ghana and the Netherlands. Population, Space and Place, 17(5), 454-468. https://doi.org/10.1002/psp.646

Millington, A., Eberhardt, M., \& Wilkinson, B. (2005). Gift Giving, Guanxi and Illicit Payments in BuyerSupplier Relations in China: Analysing the Experience of UK Companies. Journal of Business Ethics, 57(3), 255-268. https://doi.org/10.1007/s10551-004-6712-y

Molina, J. L., Valenzuela-García, H., Lubbers, M. J., García-Macías, A., \& Pampalona, J. (2015). Looking Inside the Ethnic Enclave: Inequality, Social Capital and Transnationalism. In Migrant Capital (pp. 154171). https://doi.org/10.1057/9781137348807_10 


\section{Transnational (Im)mobilities and Informality in Europe}

Molinero Gerbeau, Y., López Sala, A., Eremenko, T., Jolivet-Guetta, M., Consterdine, E., Samuk Carignani, S., \& Beauchemin, C. (2016). Seasonal Immigrant Workers and Programs in UK, France, Spain and Italy. https://doi.org/10.13140/RG.2.2.35908.01929

Morris, J., \& Polese, A. (2014). Introduction: Enduring Practices, Entwined Livelihoods. In J. Morris \& A. Polese (Eds.), The informal post-socialist economy: embedded practices and livelihoods (pp. 1-18). London and New York: Routledge.

Palmier, L. (1983). Bureaucratic Corruption and its Remedies. In M. Clark (Ed.), Corruption: Causes, Consequences and Control (pp. 207-220). New York: St. Martin's Press.

Polese, A. (2015). Informality Crusades: Why Informal Practices are Stigmatised, Fought and Allowed in Different Contexts According to an Apparently Ununderstandable Logic. Caucasus Social Science Review (CSSR), 2(1), 1-26. Retrieved from http://openjournals.gela.org.ge/index.php/ CSSR/article/ view/ $1648 / 933$

Polese, A. (2016). Limits of a Post-Soviet State: How Informality Replaces, Renegotiates and Reshapes Governance in PostSoviet Ukraine. Stuttgart: Ibidem Verlag.

Polese, A., Kovács, B., \& Jancsics, D. (2018). Informality 'in Spite of' or 'Beyond' the State: Some Evidence from Hungary and Romania. European Societies, 20(2), 207-235. https://doi.org/10.1080/ 14616696.2017.1354390

Polese, A., Morris, J., Kovács, B., \& Harboe, I. (2014). "Welfare States" and Social Policies in Eastern Europe and the Former USSR: Where Informality Fits In? Journal of Contemporary European Studies, 22(2), 184 198. https://doi.org/10.1080/14782804.2014.902368

Polese, A., Russo, A., \& Strazzari, F. (2019). Governance Beyond the Law: The Immoral, The Illegal, The Criminal. In Public Sector Economics (Vol. 43). https://doi.org/10.3326/pse.43.3.6

Polese, A., Williams, C. C., Horodnic, I. A., \& Bejakovic, P. (2017). The Informal Economy in Global Perspective: Varieties of Governance. https://doi.org/10.1007/978-3-319-40931-3

Portes, A. (2001). Introduction: The Debates and Significance of Immigrant Transnationalism. Global Networks, 1(3), 181-194. https://doi.org/10.1111/1471-0374.00012

Portes, A., Guarnizo, L. E., \& Landolt, P. (1999). The Study of Transnationalism: Pitfalls and Promise of an Emergent Research Field. Ethnic and Racial Studies, 22(2), 217-237. https://doi.org/10.1080/ 014198799329468

Rossell Hayes, A., \& Dudek, C. M. (2019). How Radical Right-Wing Populism Has Shaped Recent Migration Policy in Austria and Germany. Journal of Immigrant \& Refugee Studies, 18(2), 133-150. https://doi.org/10.1080/ 15562948.2019.1587130

Routh, S. (2011). Building Informal Workers Agenda: Imagining "Informal Employment" in Conceptual Resolution of 'Informality .' Global Labour Journal, 2(3), 208-227.

Salazar, N. B. (2014). Anthropology. In P. Adey, D. Bissell, K. Hannam, P. Merriman, \& M. Sheller (Eds.), The Routledge Handbook of Mobilities (pp. 55-63). London \& New York: Routledge.

Sandoz, L. (2020). Understanding Access to the Labour Market Through Migration Channels. Journal of Ethnic and Migration Studies, 46(1), 222-241. https://doi.org/10.1080/1369183X.2018.1502657

Schendel, W. van., \& Abraham, I. (2005). Illicit Flows and Criminal Things : States, Borders, and the Other Side of Globalization. Bloomington: Indiana University Press.

Scott, J. C. (1976). The Moral Economy of the Peasant: Rebellion and Subsistence in Southeast Asia. New Haven: Yale University Press.

Scott, J. C. (1985). Weapons of the Weak. Everyday Forms of Peasant Resistance. New Haven and London: Yale University Press.

Scott, J. C. (2012). Two Cheers for Anarchism: Six Easy Pieces on Autonomy, Dignity, and Meaningful Work and Play. Princeton: Princeton University Press.

Sheller, M. (2018). Mobility Justice: The Politics of Movement in an Age of Extremes. London: Verso.

Sheller, M., \& Urry, J. (2006). The New Mobilities Paradigm. Environment and Planning A: Economy and Space, 38(2), 207-226. https://doi.org/10.1068/a37268

Turaeva, R. (2014). Mobile Entrepreneurs in Post-Soviet Central Asia. Communist and Post-Communist Studies, 47(1), 105-114. https://doi.org/10.1016/j.postcomstud.2014.02.001

Urinboyev, R., \& Polese, A. (2016). Informality Currencies: A Tale of Misha, his Brigada and Informal Practices Among Uzbek labour Migrants in Russia. Journal of Contemporary Central and Eastern Europe, 24(3), 191-206. https://doi.org/10.1080/0965156X.2016.1261215 
Waldinger, R. (2015). The Cross-border Connection. Immigrants, Emigrants and their Homelands. Cambridge: Harvard University Press.

Williams, C. C., \& Onoshenko, O. (2014). The Diverse Livelihood Practices of Healthcare Workers in Ukraine. In The Informal Post- Socialist Economy: Embedded Practices and Livelihoods (pp. 21-34). London \& New York: Routledge.

Wimmer, A., \& Glick Schiller, N. (2002). Methodological Nationalism and Beyond: Nation-state Building, Migration and the Social Sciences. Global Networks, 2(4), 301-334. https://doi.org/10.1111/14710374.00043

Yalcin-Heckmann, L. (2014). Informal Economy Writ Large and Small: From Azerbaijani Herb Traders to Moscow Shop Owners. In J. Morris \& A. Polese (Eds.), The Informal Post-Socialist Economy: Embedded Practices and Livelihoods (pp. 165-185). London and New York: Routledge.

Zani, B. (2019). Gendered Transnational Ties and Multipolar Economies: Chinese Migrant Women's WeChat Commerce in Taiwan. International Migration, 57(4), 232-246. https://doi.org/10.1111/ imig.12526 